\title{
RESIDENTIAL VERSUS COMMUNITY CARE
}


Also by the author:

Women and Attempted Suicide

Empowerment in Community Care (editor) 


\section{RESIDENTIAL VERSUS COMMUnity CARE}

The Role OF INSTITUTIONS IN

Welfare Provision

edited by

Dr Raymond Jack

MACMILLAN 
Selection, editorial matter and Introduction (C) Dr Raymond Jack 1998

Individual chapters (in order) (C) Raymond Jack; Naom Trieman and Julian Leff; Greg Mantle; Bleddyn Davies; David Brandon; Department of Health; Kathleen Jones; Yvonne Shemmings; Sally J. Redfern;

Leonie Kellaher; Mervyn Eastman; Richard Clough 1998.

All rights reserved. No reproduction, copy or transmission of this publication may be made without written permission.

No paragraph of this publication may be reproduced, copied or transmitted save with written permission or in accordance with the provisions of the Copyright, Designs and Patents Act 1988, or under the terms of any licence permitting limited copying issued by the Copyright Licensing Agency limited, 90 Tottenham Court Road, London W1P 9HE.

Any person who does any unauthorised act in relation to this publication may be liable to criminal prosecution and civil claims for damages.

The authors have asserted their rights to be identified as the authors of this work in accordance with the Copyright, Designs and Patents Act 1988.

First published 1998 by

MACMILLAN PRESS LTD

Houndmills, Basingstoke, Hampshire RG21 6XS

and London

Companies and representatives throughout the world

ISBN 978-0-333-66518-3

ISBN 978-1-349-14135-7 (eBook)

DOI 10.1007/978-1-349-14135-7

A catalogue record for this book is available from the British Library.

This book is printed on paper suitable for recycling and made from fully managed and sustained forest sources.

$\begin{array}{cccccccccc}10 & 9 & 8 & 7 & 6 & 5 & 4 & 3 & 2 & 1 \\ 07 & 06 & 05 & 04 & 03 & 02 & 01 & 00 & 99 & 98\end{array}$

Editing and origination by Aardvark Editorial, Mendham, Suffolk 
to my parents, Herbert and Beryl 


\section{CONTENTS}

Notes on Contributors

1 Institutions in Community Care Raymond Jack

2 Closing Psychiatric Hospitals - Some Lessons from the TAPS Project

Naom Trieman and Julian Leff

3 Punishment in the Community and the Future of Prison

Greg Mantle

4 Shelter-with-Care and the Community Care

Reforms - Notes on the Evolution of

Essential Species

Bleddyn Davies

5 The Monastic Tradition and Community Care David Brandon

6 Respite Care in Homes and Hospitals

Jo Moriarty and Enid Levin

7 'We Need the Bed' - Continuing Care and Community Care

Kathleen Jones 
viii CONTENTS

8 Death and Dying in Residential Homes for Older People

Yvonne Shemmings

9 Long-term Care: Is There Still a Role for Nursing?

Sally J. Redfern

10 When and How Institutions Do Work - The Caring in Homes Initiative

Leonie Kellaher

11 Why and When Institutions Do Not

Work - Sans Everything Revisited

Mervyn Eastman

12 The Future of Residential

Care - A Personal View

Richard Clough

Index 


\section{Notes ON CONTRIBUTORS}

Professor David Brandon is Professor of Community Care at Anglia Polytechnic University, Chelmsford. He was a social work practitioner, a Buddhist monk and, subsequently, Regional Director of MIND (The National Association for Mental Health) before becoming a teacher and researcher. He has been an influential advocate of community and user-led services, particularly for people with learning difficulties and mental health problems.

Richard Clough is General Secretary of the Social Care Association, an independent organisation which has long been an influential force in the development of policy and practice in residential care in Britain.

Professor Bleddyn Davies is Director of the Personal Social Services Research Unit at the University of Kent and the London School of Economics, which, for two decades, has been internationally influential in research in community care policy and practice.

Mervyn Eastman is Director of Social Services in the London Borough of Enfield. For many years, he was a practitioner and manager of services for older people, with a particular interest in elder abuse - conducting one of the earliest British studies of elder abuse and subsequently writing widely on the subject.

Dr Raymond Jack is Reader in Social Work at Anglia Polytechnic University, Chelmsford. Following 14 years of social work practice, he has been a teacher and researcher for ten years in various universities. He has written widely on community care policy and practice.

Professor Kathleen Jones is Emeritus Professor of Social Policy at the University of York. She has been researching the role of institutions in mental health in Britain, Europe and the USA for many years and has written extensively on the implementation of community care policy and practice in relation to people with psychiatric disorders. 
Leonie Kellaher is a researcher at the Centre for Environmental and Social Studies in Ageing at the University of North London. She has written widely on the influence of environmental factors on the quality of care and the quality of life for residents of residential homes.

Jo Moriarty and Enid Levin are researchers for the National Institute for Social Work, London. They are both concerned with the longterm care of elderly and disabled people and the role of residential and community care services in maintaining them. They have recently completed and published a major study of respite care services.

Professor Sally Redfern is Director of the Nursing Research Unit at Kings College, London. She has a particular interest in the support of elderly people in long-stay settings and the future role of the nursing profession in residential and community care.

Yvonne Shemmings was, for many years, a social work practitioner and subsequently senior manager of elder care services for Essex County Council. She has recently completed and published a research study on death and dying in residential homes.

Dr Naom Trieman is Assistant Director and Professor Julian Leff is Honorary Director of the "Team for the Assessment of Psychiatric Services' (TAPS) at the Institute of Psychiatry, London University, which for almost a decade has been researching the effects of mental hospital closure on patients and community care services in London. 